\title{
People and Environment: A Quantitative Analysis of Attitudes and Behavior toward Media of Urban Green Spaces
}

\author{
Worawan Ongkrutraksa
}

\begin{abstract}
This research aims to complement existing research to be completed as well as study people's media exposure and attitudes toward media of green spaces. It also aims to explore people's behavior and improve methods of communication to be more efficient and provide a guideline for content creation to match target audience needs and levels of awareness about environmental problems. Lastly, the results of the study should benefit communicators in planning media for urban green spaces in the future.

This quantitative research was conducted by a survey distributed to 400 adults who live in Bangkok. The results show that the samples had a positive attitude towards going to a park to exercise to get healthy rather than improve their body image. It also shows that media can encourage engagement with green spaces as well as share their experience through online media and television because these clearly portray benefits of green spaces which in turn motivates concern about the environment.
\end{abstract}

Index Terms-Green spaces, people's attitudes toward media.

\section{INTRODUCTION}

Due to today's environmental issues caused by global warming, Thailand is now affected by natural phenomena such as high air pollution. Since Bangkok's environmental problems significantly affect people's quality of life, both public and individual urban green space (e.g. public parks, vegetable gardens, vertical gardens and rooftop gardens) is essential for a healthy life. However, developing the city to increase sustainable green spaces needs collaboration from many sectors, especially the public. If people have positive attitudes toward media concerning green spaces as well as have media participation and activities with green spaces, green space development can become more efficient.

Nowadays, communication channels are significantly increased and target audiences can access many of these channels freely. Moreover, from previous research, there are still no specific studies on media of urban green space in Thailand. Therefore, this study aims to open up a new field of knowledge which will include current research to be completed as well as study people's media exposure and attitudes toward media of green spaces. It also aims to explore about people's behavior and hence improve methods of communication to be more efficient and provide a

Manuscript received May 10, 2019; revised July 25, 2019. This work was supported by the Faculty of Communication Arts, Chulalongkorn University's research Grant.

Worawan Ongkrutraksa is with Faculty of Communication Arts, Chulalongkorn University, Thailand (e-mail: worawan.o@ chula.ac.th). guideline for content creation to match target audience needs and levels of awareness about environmental problems. Lastly, the results of the study should benefit communicators in planning media for urban green spaces in the future.

\section{A. Research Objectives}

1) To investigate media or Integrated Marketing Communications (IMC) of urban green space, which is a new field of study for communications

2) To gain knowledge about media exposure of urban green space, attitudes towards media of urban green space and people's behavior such as media participation and activities in urban green space

3) To adapt the obtained knowledge to further develop practitioners in the field of marketing communications and public relations for better understanding of how to make urban green spaces sustainable by using marketing communications and public relations

\section{LITERATURE REVIEW}

\section{A. Integrated Marketing Communications (IMC)}

Integrated Marketing Communications (IMC) is a circular process of marketing communication for certain periods of time to adjust direction and manage fluctuations in communication by using and developing marketing tools such as advertising, sales promotion and personal selling, and combine these tools with certain media such as billboards to serve as touch points that will expose consumers to certain media and persuade specific target audiences for a specific period of time [1].

Nowadays, marketing communication in the form of event marketing has become an essential communication channel for entrepreneurs because it is not only product promotion or service, but also encourages the sale of a good or service and even creates hype for products or activities. Event marketing contains four elements: 1) Brand experience to show brand identity, 2) Message delivery through activities, 3) Gaining more attention from niche targets and 4) Leading, supporting and amplification of IMC tools. Most of all, continuous event marketing can efficiently create brand personality [2].

Regarding consumers in Bangkok and their attitude, buying decision and brand loyalty towards high and low involvement products that feature event marketing, it was found that consumers' participation in event marketing affects their buying decision when emphasizing the importance and effectiveness of event marketing on current proactive marketing. Therefore, event marketing can be 
adapted to communication about the environment to reach target audiences such as communities as they are a social unit that plays a significant role in local natural resources conservation. Since communities' behavior can vary according to the local environment, natural resources conservation should start at creating understanding by an entire community that will lead to participation in conserving natural resources sustainably [3]. These ideas about IMC were used to generate the questionnaire for the media exposure part of this study's survey.

\section{B. Related Research}

Kittipong Jirawaswong (2012) [4] defined environmental communication as a method of communication designed to understand and reassure society regarding environmental issues caused by activities, products and services. Effective environmental communication should be able to raise awareness and consciousness about the natural environment to support culture, responsibilities and values concerning the environment within a community or organization to manage issues and complaints, gain acceptance and reassure shareholders. There are five main principles of environmental communication:

1) Transparency

2) Appropriateness

3) Credibility

4) Responsiveness

5) Clarity

Ongkrutraksa (2017) [5] stated that urban green spaces in Bangkok can be divided into five types: 1) Government recreational park, 2) Government green space for food production, 3) Non-government recreational park, 4) Non-government green space for food production and 5) Other green spaces.

It was found in this research that sustainable green spaces require community members' recognition of the benefits of green spaces. This awareness can be raised by media and communication that are suitable for each person.

As far as urban green space usage of people living in Bangkok, [6] stated that people in Bangkok are enthusiastic about urban green spaces, especially public parks where they can spend time with family and friends during the weekend exercising or engaging in other activities. Roadside and indoor green spaces in, for example, shopping malls are also popular in Bangkok. This study estimated that each person living in Bangkok has approximately 3.52 sq.m. of green space, which is below international standard. However, each family agreed to spend approximately 750.48 Baht on the construction of green spaces, giving urban green spaces in Bangkok a value of 1.69 trillion Baht.

In addition, from the research, "Building relationships, accessing resources: Mobilizing social capital in community garden contexts", which focused on understanding relationship building through a park supported by a community's leader, it was found that building relationships through leisure activities in community's green spaces is a key to stronger relationships within the community [7].

\section{RESEARCH METHOdOLOGY}

This research was conducted in 2017 to 2018 employing a questionnaire distributed to 400 people aged over 18 living in Bangkok. This group consisted of teenagers and middle-aged people who had experience in media exposure and interested in social matters [8].

In the questionnaires, participants were asked the following questions about parks or urban green spaces:

- "What is your opinion and reason to go to a park?"

- "Which kind of media of "a park" do you receive and from whom?"

- "Which media of a park do you feel they are useful?"

- "Which media encourages your interest to go/participate in activities of a park such as learning to plant trees or vegetables, watching concerts, going to flea markets, etc.?"

The research employed questions from previous and related studies that have already been tested for validity and reliability. Then, a pre-test of the questionnaire was conducted with 30 samples to prove understanding of the questionnaire and test reliability before launching the rest of the questionnaires. Cronbach's Alpha Coefficient was applied to test reliability of this study' exposure to urban green spaces' media, which is equal to 0.854 , and attitude towards IMC of urban green spaces, which is equal to 0.849 .

\section{RESUlTS}

From 400 participants in this study, 362, or $90.50 \%$, showed concern about environmental problems.

\section{A. Reason to Go to Green Spaces}

Table I showing number, mean, standard deviation and attitude level of "opinion about going to a park" proves that samples had a positive attitude towards going to a park or doing some activities there, with average scores from 3.41 to $5.00(\bar{x}=4.00)$.

TABLE I: SAMPLES' OPINIONS AND REASONS TO GO TO A PARK

\begin{tabular}{|c|c|c|c|c|}
\hline $\begin{array}{l}\text { "What is your } \\
\text { opinion and } \\
\text { reason to go to a } \\
\text { park?" }\end{array}$ & Quantity & Mean & $\begin{array}{l}\text { Standard } \\
\text { Deviation }\end{array}$ & $\begin{array}{l}\text { Attitude } \\
\text { Level }\end{array}$ \\
\hline $\begin{array}{l}\text { - If you have } \\
\text { free time, } \\
\text { you will go } \\
\text { to a park or } \\
\text { do some } \\
\text { activities at } \\
\text { a park such } \\
\text { as } \\
\text { exercising, } \\
\text { walking, } \\
\text { learning to } \\
\text { plant, etc. }\end{array}$ & 400 & 4.00 & 0.92 & Positive \\
\hline $\begin{array}{l}\text { You go to a } \\
\text { park to } \\
\text { exercise for } \\
\text { good health, } \\
\text { preventing } \\
\text { sickness. }\end{array}$ & 399 & 3.89 & 0.97 & Positive \\
\hline
\end{tabular}




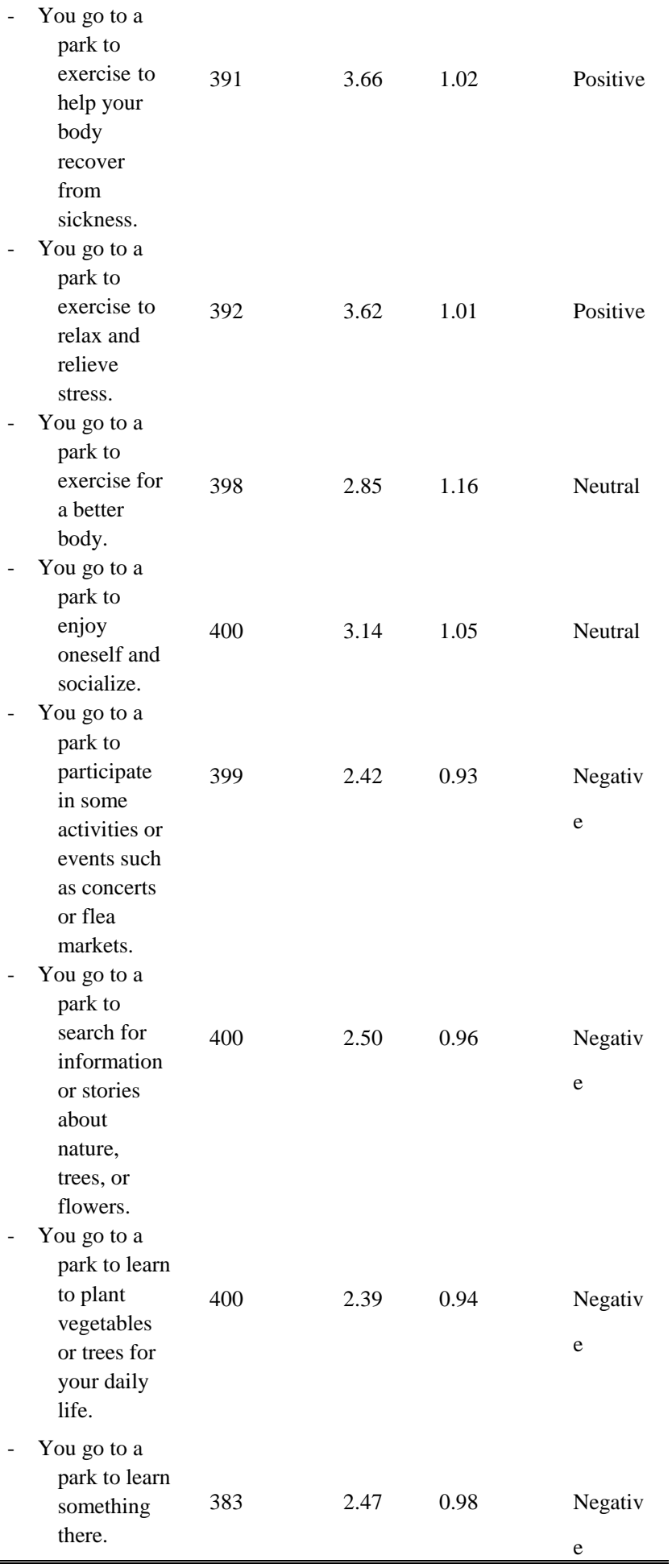

The study found that samples had a positive attitude towards going to a park with scores ranging from 3.41 to 5.00 , stating that they would go to a park to exercise to be healthy (3.89), recover from illness (3.66) and relax (3.62). There were also samples who had a neutral attitude towards going to a park with scores ranging from 2.61 to 3.40 , mentioning that they would go to a park to exercise for a better body (2.85) and socialize (3.14). Lastly, samples who had negative attitude towards going to a park had scores ranging from 1.81 to 2.60 , stating that they would go to a park to participate in events and search for information and stories about nature (2.50), take courses (2.39) and gain knowledge from a park (2.47)

\section{B. Exposure to Media of Urban Green Spaces}

Table II shows amount, mean, standard deviation and exposure level of "Which kind of media of "a park" do you receive information from? "The study found that samples have been exposed neutrally through three media channels with average scores between 2.01-3.00 such as online media (e.g. Facebook, Line, YouTube, and Website) (2.98), traditional media (e.g. television, radio, newspaper, magazine, or signboard) (2.90), and people (e.g. relatives, friends, acquaintances or leaders in a community) (2.68).

TABLE II: SAMPleS' EXPOSURE TO URBAN GREEN SPACES’ Media

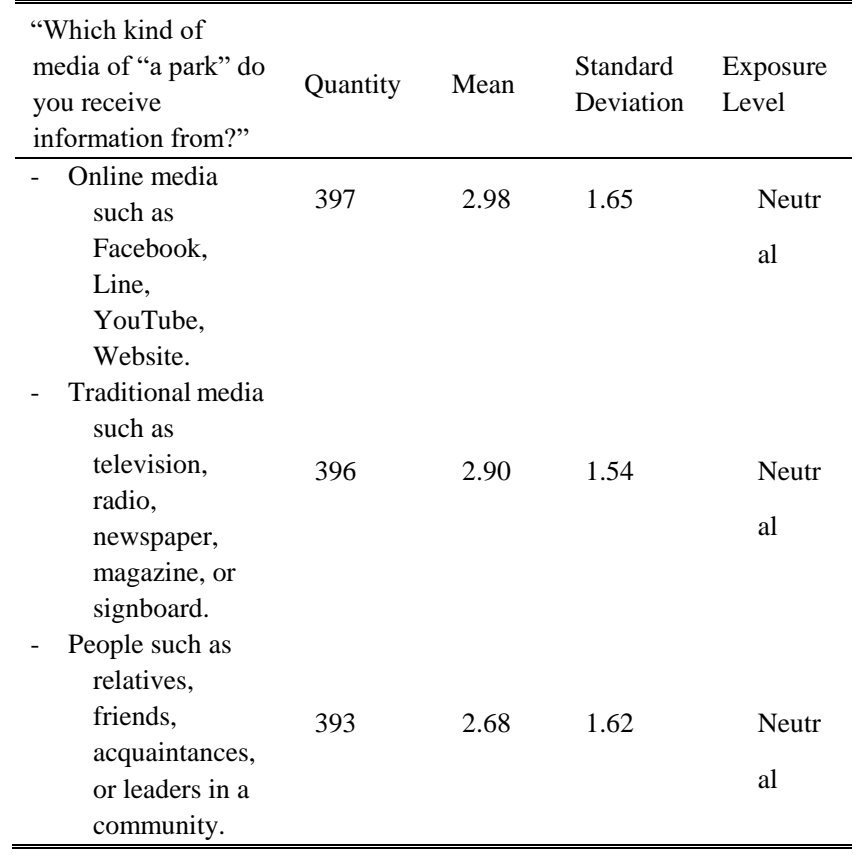

\section{Attitude towards Media of Urban Green Spaces}

Which media of a park do you feel are useful?

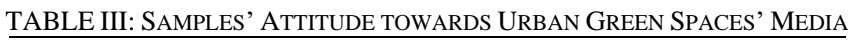

\begin{tabular}{lllll}
\hline \hline $\begin{array}{l}\text { "Which media of a } \\
\text { park that you feel } \\
\text { they are useful?" }\end{array}$ & Quantity & Mean & $\begin{array}{l}\text { Standard } \\
\text { Deviation }\end{array}$ & $\begin{array}{l}\text { Attitude } \\
\text { Level }\end{array}$ \\
\hline - $\begin{array}{l}\text { Online media } \\
\text { such as }\end{array}$ & 400 & 3.79 & 1.05 & Positi \\
$\begin{array}{l}\text { Facebook, } \\
\text { Line, } \\
\text { YouTube, }\end{array}$ & & & ve \\
$\quad \begin{array}{l}\text { Website. } \\
\text { Traditional media } \\
\text { such as } \\
\text { television, } \\
\text { radio, } \\
\text { newspaper, } \\
\text { magazine, } \\
\text { signboard. }\end{array}$ & 398 & 3.47 & 0.90 & Positi \\
$\begin{array}{l}\text { People such as } \\
\text { relatives, } \\
\text { friends, } \\
\text { acquaintances, } \\
\text { or leaders in a } \\
\text { community. }\end{array}$ & & & & ve \\
\hline \hline
\end{tabular}

Table III shows amount, mean, standard deviation, and attitude level of "Which media of a park do you feel are useful?" The study found that samples had positive attitude 
with average scores 3.41-5.00. Media that the samples felt useful are online media (e.g. Facebook, Line, YouTube, and Website) (3.79), traditional media (e.g. television, radio, newspaper, magazine, or signboard) (3.47). There were also samples that had neutral attitude with average scores between 2.61-3.40 for communication with relatives, friends, acquaintances and community leaders (3.38).

\section{Behavior towards Media of Urban Green Spaces}

Which media makes you feel interested to go/participate in activities of a park such as learning to plant trees or vegetables, watching concerts, going to flea markets, etc.?

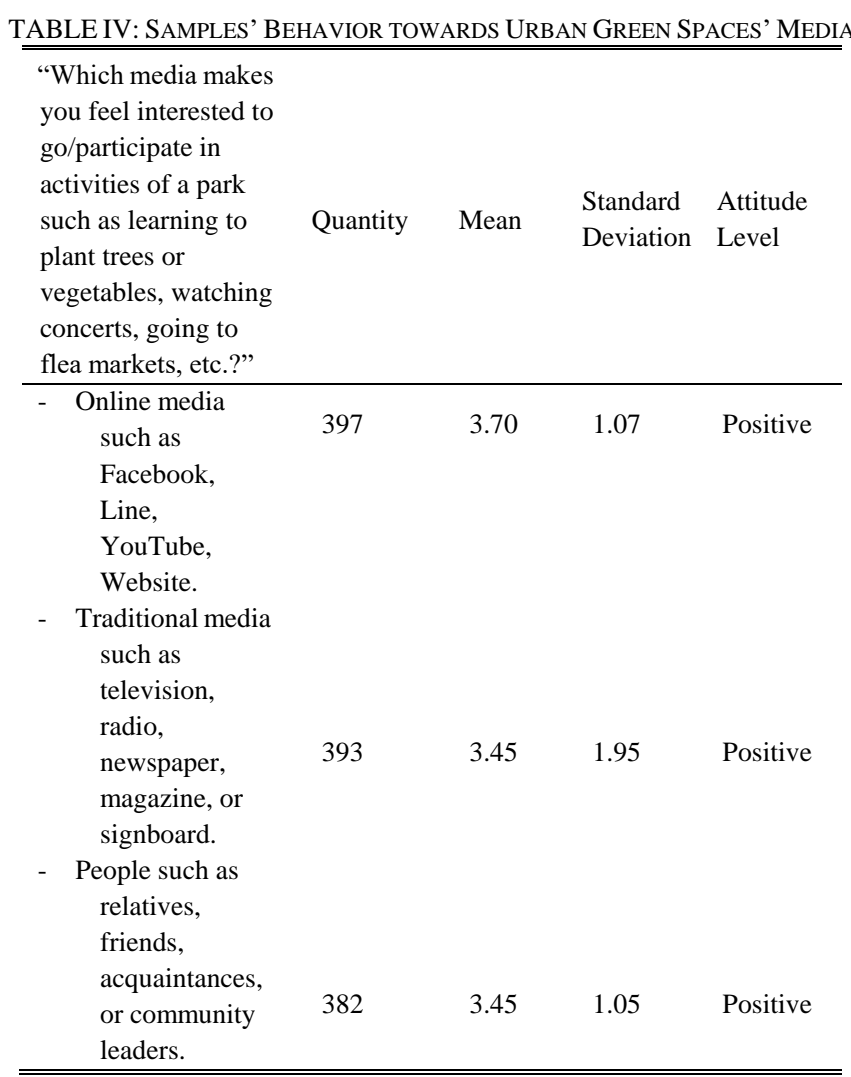

TABLE V: SURVEY RESUltS OF AN OPEN-ENDED QUESTION ABOUT SAMPLES' OPINIONS ON WHICH COMMUNICATION CHANNELS MAKE PEOPLE Want to Engage With GreEn Spaces Sustainably and Share What THEY GET THE MOST FROM THEM

\begin{tabular}{|c|c|c|}
\hline Media genre & Communication channels & $\begin{array}{l}\text { Communication } \\
\text { types }\end{array}$ \\
\hline Online media & $\begin{array}{l}\text { Facebook } \\
\text { Line } \\
\text { YouTube } \\
\text { Website }\end{array}$ & $\begin{array}{l}\text { YouTube clips and } \\
\text { social media posts } \\
\text { about nature } \\
\text { conservation }\end{array}$ \\
\hline Traditional media & $\begin{array}{l}\text { Television } \\
\text { Mass media } \\
\text { Signboard } \\
\text { Newspaper }\end{array}$ & $\begin{array}{l}\text { Signboards, video } \\
\text { clips, or TV } \\
\text { programs about } \\
\text { nature conservation, } \\
\text { showing effects of } \\
\text { deforestation }\end{array}$ \\
\hline People & $\begin{array}{l}\text { Relatives } \\
\text { Friends } \\
\text { Acquaintances } \\
\text { Community leaders }\end{array}$ & $\begin{array}{l}\text { Direct talking, } \\
\text { community's public } \\
\text { relations, and } \\
\text { word-of-mouth }\end{array}$ \\
\hline
\end{tabular}

Table IV shows amount, mean, standard deviation and attitude level of "Which media makes you feel interested to go/participate in activities of a park such as learning to plant trees or vegetables, watching concerts, going to flea markets, etc.?" The study found that samples had a positive attitude with average scores 3.41-5.00; online media (e.g. Facebook, Line, YouTube, and Website) (3.70), traditional media (e.g. television, radio, newspaper, magazine, or signboard) (3.45) and people (e.g. relatives, friends, acquaintances and community leaders) (3.45).

In addition, Table $\mathrm{V}$ shows samples' opinions on communication, positing that all three media channels, namely online and traditional media, as well as people, should be used to promote green spaces. Also, people should visit green spaces to see how they would be like to live with green spaces. Lastly, green spaces should be clean, safe and well-maintained to make people want to come and the spaces sustainable.

\section{CONCLUSION AND DISCUSSION}

400 samples who live or work in Bangkok contained $56.25 \%$ female and $43.75 \%$ male. $30.25 \%$ of the sample were aged between 28-37 years old. $49.50 \%$ graduated with a bachelor's degree or equivalent. Lastly, $37.50 \%$ were employees. This study divided samples' consciousness about nature into two groups; less conscious and more conscious. There were 38 samples, or $9.50 \%$, who thought that environmental problems were not their concern while 362, or $90.50 \%$ of all participants thought that environmental problems were critical. It could be concluded that most of the sample are concerned about environmental problems.

The samples who had a positive attitude towards going to a park thought that they would go there to exercise to be healthy and prevent illness. Next, the samples with neutral attitude thought that they would go there to exercise for a better body and socialize. Lastly, the samples with negative attitude thought that they would go to participate in events and search for information and stories about nature.

The samples have been moderately exposed to media of urban green spaces through three media channels, online media, traditional media and people. Participants felt that online media and traditional media provided useful information and news about green spaces. In addition, online media, traditional media and people were persuasive in encouraging samples to go to a park and participate in events there.

Results from open-ended questions about the samples' opinions about which communication channels and styles that make people attracted to green spaces and share benefits they get from these spaces. From 45 answers, 17 stated that online media and traditional media, especially television, should be used to make people attracted to green spaces and share benefits they get from these spaces. Some interesting opinions from samples as presented below:

- A park should be kept clean, safe and well-maintained so people in a community can do activities together and recognize the importance of that space to make it sustainable.

- Communications about green spaces, namely online media, traditional media and people, should be integrated and collaborated by everyone in a community, especially 
community leaders.

- There should be signboards or TV series about effects of exploitation of natural resources such as flooding from deforestation.

- Online media is easy to access but what might be better to make people attracted to a park should be activities.

The study found that samples had a positive attitude towards going to a park to exercise to be healthy and prevent illness. Also, those who had neutral attitude tended to go to a park to exercise for a better body and socialize. The results of this study prove that people who live in Bangkok are enthusiastic about urban green spaces, especially public parks where they can spend their time on weekends with family and friends, which are similar to the findings of Bejranonda (2011) [6]. Moreover, all three media genres, online, traditional as well as people, which samples have been exposed to moderately, are considered as effective means of communication, depending on the communication objectives and context (Ongkrutraksa, 2017) [5]. Lastly, this study proposes four topics for further discussion as follows:

1) Integrated Marketing Communications (IMC) for five kinds of urban green spaces: government recreational park, government green space for food production, non-government recreational park, non-government green space for food production and other green spaces, which could use online media to spread word of mouth such as sharing stories about a park's activity on social media.

2) Positive attitude towards going to a park to exercise to get healthy rather than have a better body.

3) Green spaces can build relationships with community members through online and traditional media, as well as through face-to-face communication that is tailored by communication objectives and context for different target groups. Moreover, media that are useful for green spaces and make the samples want to go there have been proven by this study to be online and traditional media. In addition, word-of-mouth communication also makes people interested to go to a park.

4) Communication methods that encourage people's engagement with green spaces sustainably and makes them share what they get from them are online media and television because they clearly portray benefits of green spaces and hence make them a concern about the environment. Also, collaboration between community leaders and people is crucial as all should know how important green spaces are to a community.

\section{CONFLICT OF INTEREST}

The author declares no conflict of interest.

\section{AUTHOR CONTRIBUTIONS}

There is only one author, so the author is the only one who responsible for contributions to this work.

\section{REFERENCES}

[1] J. C. Soodsuk, "Integrated marketing communications for Thai product in Vietnam," Thesis, Master of Arts (Communication Arts), Chulalongkorn University, Bangkok, 2016.

[2] K. Kanjanapokin, Event Marketing, Bangkok: Krungthep Turakij Media, 2012.

[3] K. Rattana. (2016). How to build learning network and participation process in developing society and environment. Industrial Estate Authority of Thailand. [Online]. Available: http://www.ieat.go.th/assets/uploads/cms/file/2016040717320711532 55149.pdf

[4] K. Jirawaswong. (2012). ISO 14063 environmental communication. technology promotion association (Thailand-Japan). Technology Promotion Association (Thailand-Japan). [Online]. Available: http://www.tpa.or.th/publisher/pdfFileDownloadS/qm171_p017-20.pd f

[5] W. Ongkrutraksa, "Communications for sustainable urban green space: A review of the literature," presented at GSCM NIDA 2nd International Conference on Innovative Communication and Sustainable Development in ASEAN (ISDA), Bangkok, August 4, 2017.

[6] S. Bejranonda. (2011). Valuation of urban green space in Bangkok, Thailand. Research Gate. [Online]. Available: https://www.researchgate.net/publication/268517079_Valuation_of_ Urban_Green_Space_in_Bangkok_Thailand

[7] T. D. Glover, D. C. Parry, and K. J. Shinew, "Building relationships, accessing resources: Mobilizing social capital in community garden contexts," Journal of Leisure Research., vol. 37, no. 4, pp. 450-474, Dec 2017.

[8] N. Ngampradit, "The effectiveness of fear appeal in picture and message towards global warming campaign," Thesis, Master of Arts (Communication Arts), Chulalongkorn University, Bangkok, 2010.

Copyright (C) 2019 by the authors. This is an open access article distributed under the Creative Commons Attribution License which permits unrestricted use, distribution, and reproduction in any medium, provided the original work is properly cited (CC BY 4.0).

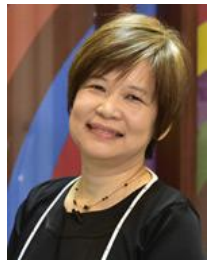

Worawan Yim Ongkrutraksa was born in Chiang Mai, Thailand. She is an associate professor in the Department of Public Relations, Faculty of Communication Arts, Chulalongkorn University, Bangkok, Thailand. She was a Monbusho (Ministry of Education, Japan) Scholarship recipient. She earned her doctor of arts (communications) from Tokai University, Kanagawa, Japan; master of letters in mass communications/advertising from the same university and earned a second master of arts in media studies (with distinction) from the New School for Social Research, New York, USA. She was first awarded a bachelor of arts in mass communications / television (first class honours) by Chiang Mai University, Thailand.

She is an organizational speaker for the Thai government, private organizations and a visiting professor at Nihon University, Japan and Henley Business School Malaysia, University of Reading Malaysia. She was an assistant to the president of Chulalongkorn University in PR and communications between 2008 and 2016. She teaches in English and Thai for undergraduate and graduate programs (Marketing communications and Society, Identity and Image Management, International Marketing Communications). She has published 17 books and articles, including Debate over Corporate Social Responsibility, Oxford University Press. Her special areas of interest are environmental communications, social media and international marketing communications. 